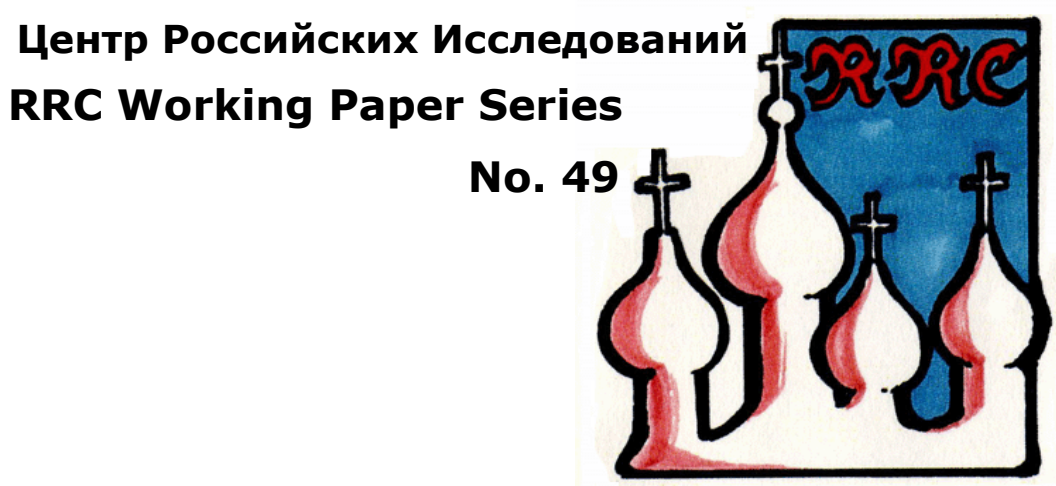

The Impact of Oil Prices, Total Factor Productivity and Institutional Weakness on Russia's Declining Growth

Masaaki KUBONIWA

November 2014

\author{
RUSSIAN RESEARCH CENTER \\ INSTITUTE OF ECONOMIC RESEARCH \\ HITOTSUBASHI UNIVERSITY \\ Kunitachi, Tokyo, JAPAN
}




\title{
The Impact of Oil Prices, Total Factor Productivity and \\ Institutional Weakness on Russia's Declining Growth ${ }^{1}$
}

\author{
Masaaki Kuboniwa \\ Institute of Economic Research \\ Hitotsubashi University
}

\section{Introduction}

This paper presents an analysis of the impact of oil prices, total factor productivity (TFP) and institutional weakness on the present growth retardation in Russia. First, I discuss Russia's dependence on oil and natural gas. I provide an estimate of the value-added of the oil and gas industry generated by revenues from domestic production and exports of oil and gas. Russia's oil windfalls are captured using the concepts of terms of trade and trading gains (terms of trade adjustment). Next, the impact of oil prices and TFP on growth is analysed using the estimation of regressions for the GDP-oil nexus and production function. The relationship between TFP and growth in the present Russian economy is investigated. Finally, the elusive impact of institutional weakness on Russia's growth is considered, using the World Bank's governance indicators (WGI) and ease of doing business index.

\footnotetext{
${ }^{1}$ I thank Dr Susanne Oxenstierna of FOI (Swedish Defence Research Agency) for her helpful comments on an earlier draft of this paper, presented at an international conference on the Economics of the Russian Politicized Economy, Norrlandsgatan, Stockholm on March 21, 2014.
} 


\section{Value-added of the oil and gas sector in Russia's GDP}

Based on Russian official statistics, the average share of value-added of oil and gas (crude oil, oil products and natural gas) in overall GDP for 2005-13 was only 10 per cent. If this were true, it cannot be claimed that Russia relies heavily on oil and gas. As shown by Kuboniwa et al. (2005), the official picture is a result of its specific methodology where all revenues from exports of oil and gas are included in the trade and transportation sectors and net taxes on exports. In order to capture the right picture of the oil and gas industry in the Russian economy, it is necessary to rearrange revenues from exports of oil and gas and export taxes on these as part of the value-added of the oil and gas sector.

Revenues of the oil and gas industry from exports are measured by the differences between exports in foreign trade prices and domestic basic prices. Exports of oil and gas in foreign trade prices are taken from foreign trade data in USD (websites of Rosstat and Bank of Russia, CIS statistical committee's annual reports on external trade of the CIS countries, the CEIC database, and OECD STAN bilateral trade database). Exports of oil and gas in basic prices are calculated by the official data on export quantities (ton or cubic meter) and annual average domestic basic prices based on quarterly or monthly data. Export taxes on oil and gas are paid from the export revenues. Data on export taxes are available from a website of the Russian Ministry of Finance or the Garant database of the federal laws of Russia. I regard all revenues from exports of oil and gas as part of the value-added of that sector at basic prices. Although export taxes can be considered to belong to a category of taxes on products or indirect 
taxes, I here consider taxes on oil and gas exports as corporate income taxes according to the usual practice in most oil exporting countries, for example Norway.

Figure 1 shows the result of our estimates for 2005-13. Figure 2 summarizes the average picture for the period. The average share of the estimated value-added of the oil and gas industry in overall GDP is 20 per cent that is twice the official figure of 10.2 per cent. The average gross revenue from oil and gas exports amounts to about 10 per cent of GDP, of which 6.8 per cent are paid to the federal government as export taxes and 3.1 per cent remain in the companies. It should be emphasized that export taxes are much larger than companies' net revenues from exports. The share of total value-added of the oil and gas industry in GDP reached its peak of 22 per cent in 2005, fell down to 17.5 per cent in 2009 due to the reverse oil shock coupled with the Lehman shock, and increased to 20 per cent in 2013.

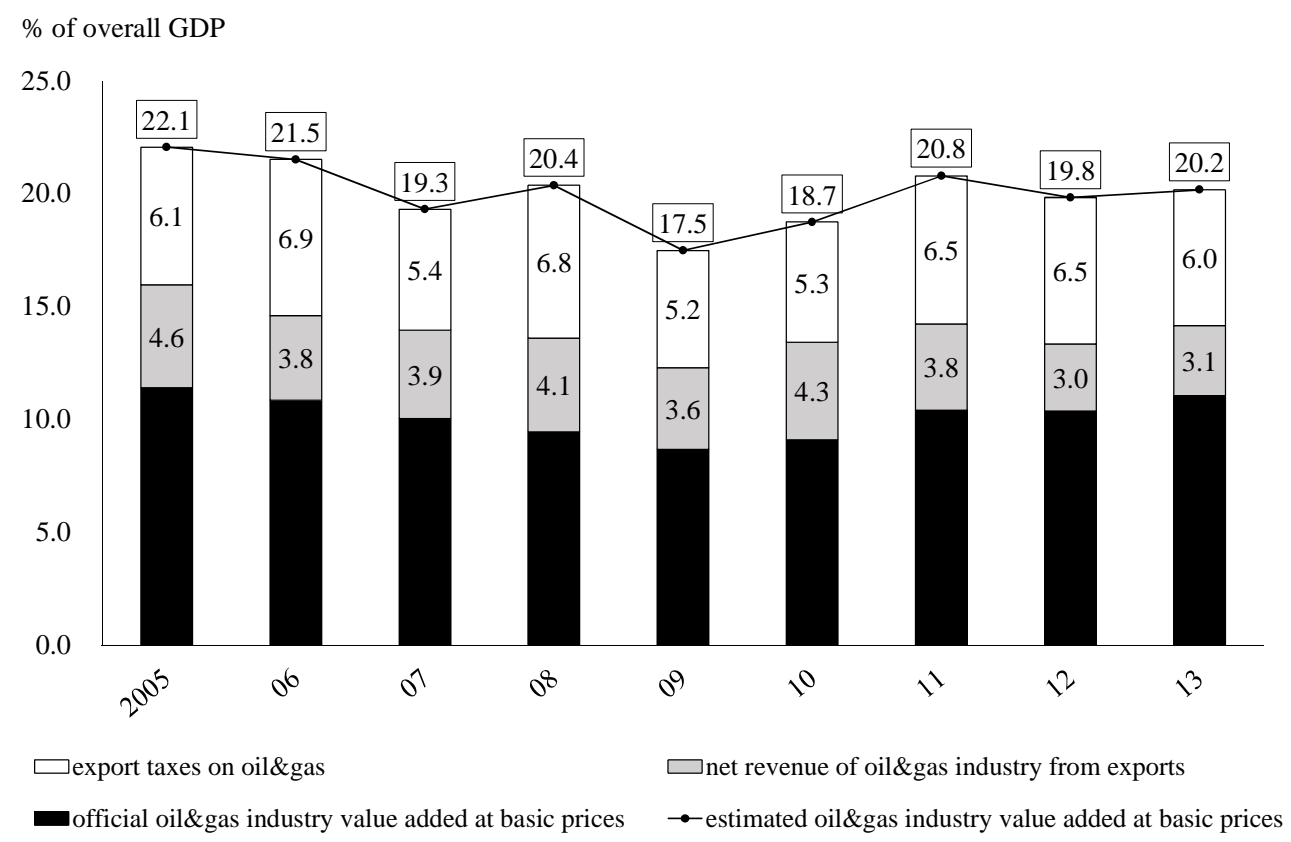

Fig. 1. Share of value-added of the oil and gas industry in overall GDP (\%)

Source: Author's calculations from Rosstat website and Ministry of Finance website. 


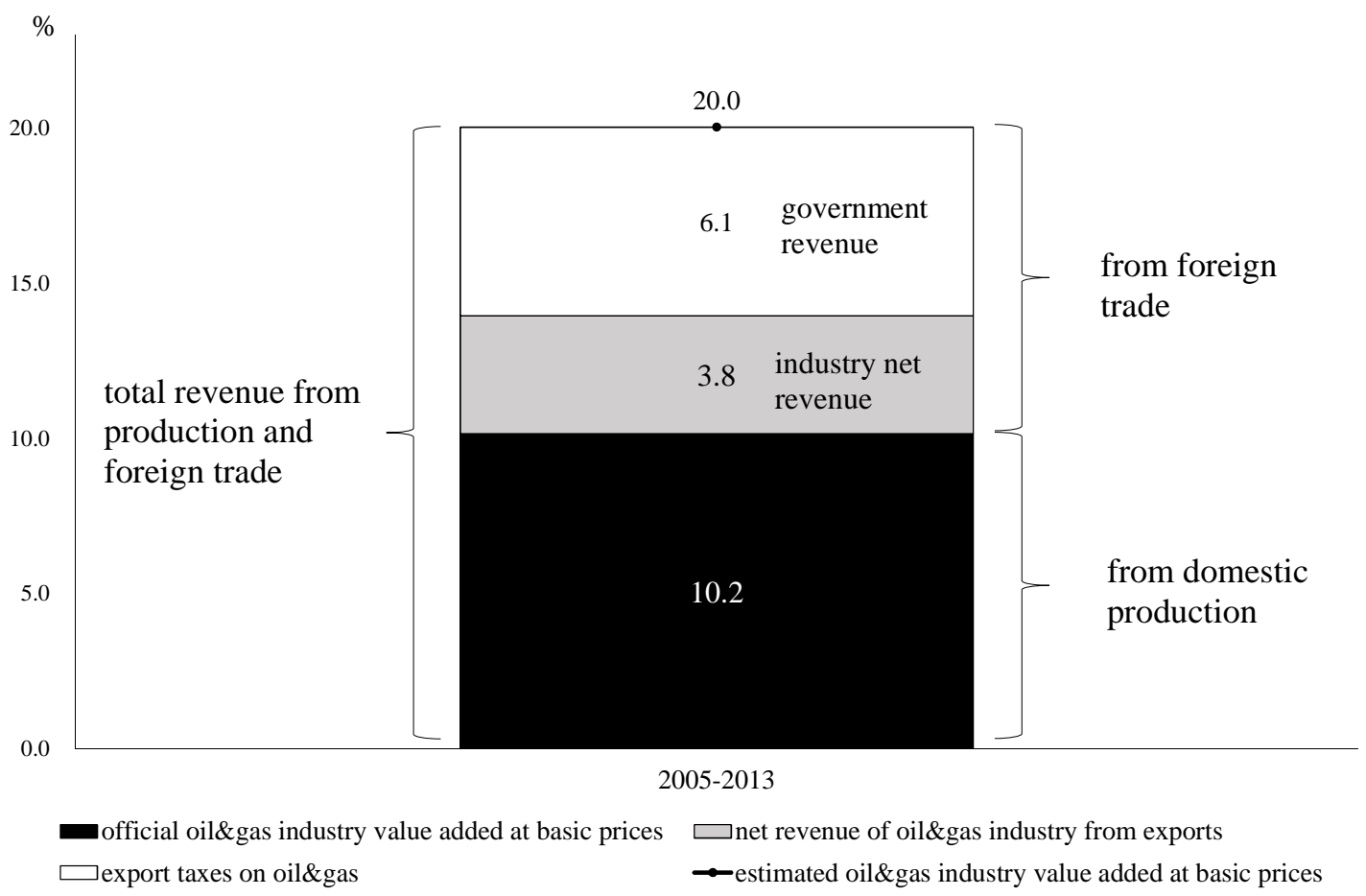

Fig. 2. Average share of value-added of the oil and gas industry in overall GDP (\%) Source: Figure 1.

The estimates of the share of total value-added of the oil and gas industry for 2005-06 are slightly smaller than the results of 24-25 per cent in Ustinova (2010) and Kuboniwa (2012) based on input-output tables because the latter includes additional domestic activities of the oil and gas industry and taxes on oil and gas other than export taxes. Due to the lack of disaggregated input-output tables from 2007 onward, our simple method may also be appropriate. It should also be noted that our estimate only considers formal activities of the oil and gas industry. However, our methodology is rather robust because it can always be reproduced from systematically written evidence. The results may also provide evidence for part of the resource rents suggested by Gaddy and Ickes (2013). 


\section{Terms of trade and trading gains}

Windfalls arising from rapidly rising oil prices for Russia can be captured by trading gains due to improvements in terms of trade. The concept of 'trading gains/losses' is explained by the system of national accounts, SNA, 1993 and 2008. This concept is called 'terms of trade adjustment' in the World Bank's WDI. According to the SNA 2008 (United Nations et al., 2008, section 15.188), the real gross domestic income (GDI) measures the purchasing power of a country's total income generated by its domestic production. The terms of trade (ToT) is defined as the ratio of the export price $\mathrm{P}^{\mathrm{e}}$ to the import price $\mathrm{P}^{\mathrm{m}}$, that is to say, $\mathrm{P}^{\mathrm{e}} / \mathrm{P}^{\mathrm{m}}$. Here, $\mathrm{P}^{\mathrm{e}}=\mathrm{E}_{\mathrm{n}} / \mathrm{E}_{\mathrm{r}}$ and $\mathrm{P}^{\mathrm{m}}=\mathrm{M}_{\mathrm{n}} / \mathrm{M}_{\mathrm{r}}$ where $\mathrm{E}_{\mathrm{n}}$ and $M_{n}$ are exports and imports in current prices, respectively, and $E_{r}$ and $M_{r}$ are exports and imports in constant prices, respectively. Due to improvements in ToT caused by the rise in export prices relative to import prices, the purchasing power of the country in international markets increases in relation to real GDP. The trading gains (TG) or terms of trade adjustment from the changes in the ToT can be formulated as nominal net exports deflated by the import price index minus the conventional real net exports:

$$
T G=\left(E_{n}-M_{n}\right) / P^{m}-\left(E_{r}-M_{r}\right)
$$

It follows from equation 1 that

$$
\mathrm{TG}=\mathrm{E}_{\mathrm{n}} / \mathrm{P}^{\mathrm{m}}-\mathrm{E}_{\mathrm{r}}=\mathrm{E}_{\mathrm{r}}\left(\mathrm{P}^{\mathrm{e}} / \mathrm{P}^{\mathrm{m}}-1\right)
$$

It follows from equation 2 that $\mathrm{TG}>=<0$ if $\mathrm{ToT}=\mathrm{P}^{\mathrm{e}} / \mathrm{P}^{\mathrm{m}}>=<1$. If the terms of trade or $\mathrm{P}^{\mathrm{e}} / \mathrm{P}^{\mathrm{m}}$ improve (worsen), the trading gains should increase (decrease). At the base period $\mathrm{P}^{\mathrm{e}}=\mathrm{P}^{\mathrm{m}}=1$ and, hence, TG must be zero.

The real GDI is defined as the real GDP plus the real trading gains: 
real GDI = real GDP + real TG.

In general, if imports and exports are large relative to GDP and if there is a marked change in ToT due to a large increase in export prices relative to import prices or a decrease in import prices relative to export prices, the magnitude of potential trading gains or losses would be large. Indeed, as will be shown, this is true for the Russian economy. It can be noted that trading gains can be spent on additional purchases of imports and domestically produced goods as well. Although, in the literature, real GDI is often discussed as an alternative welfare concept in place of, or in addition to, real GDP, Kuboniwa $(2012,2014)$ focuse on the impact of changes in terms of trade or trading gains (losses) on real GDP.

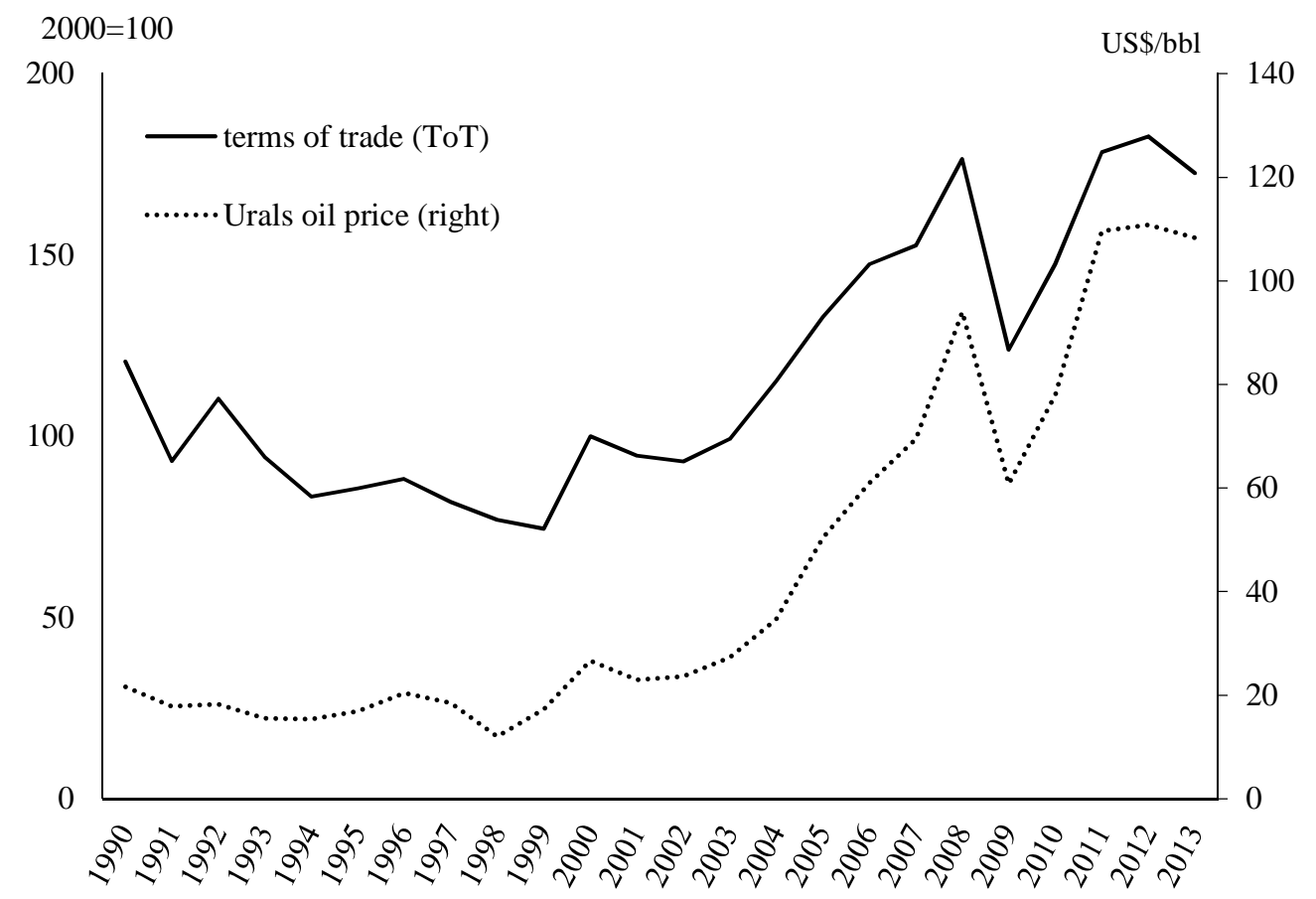

Fig. 3. Oil prices and terms of trade

Source: WDI, Bloomberg-Thomson Reuters and author's estimates. 
Figure 3 shows annual data on movements of ToT along with Urals oil prices for 1990-2013 in Russia. As can be seen, the ToT has a strong positive relationship with oil prices. In 2000-8, rising oil prices caused large improvements in ToT. Huge improvements in ToT with rapidly rising oil prices imply that import prices did not show any large increases in response to oil shocks. Unlike the 1970s, the 2000s did not witness sufficiently parallel changes in import prices with oil prices.

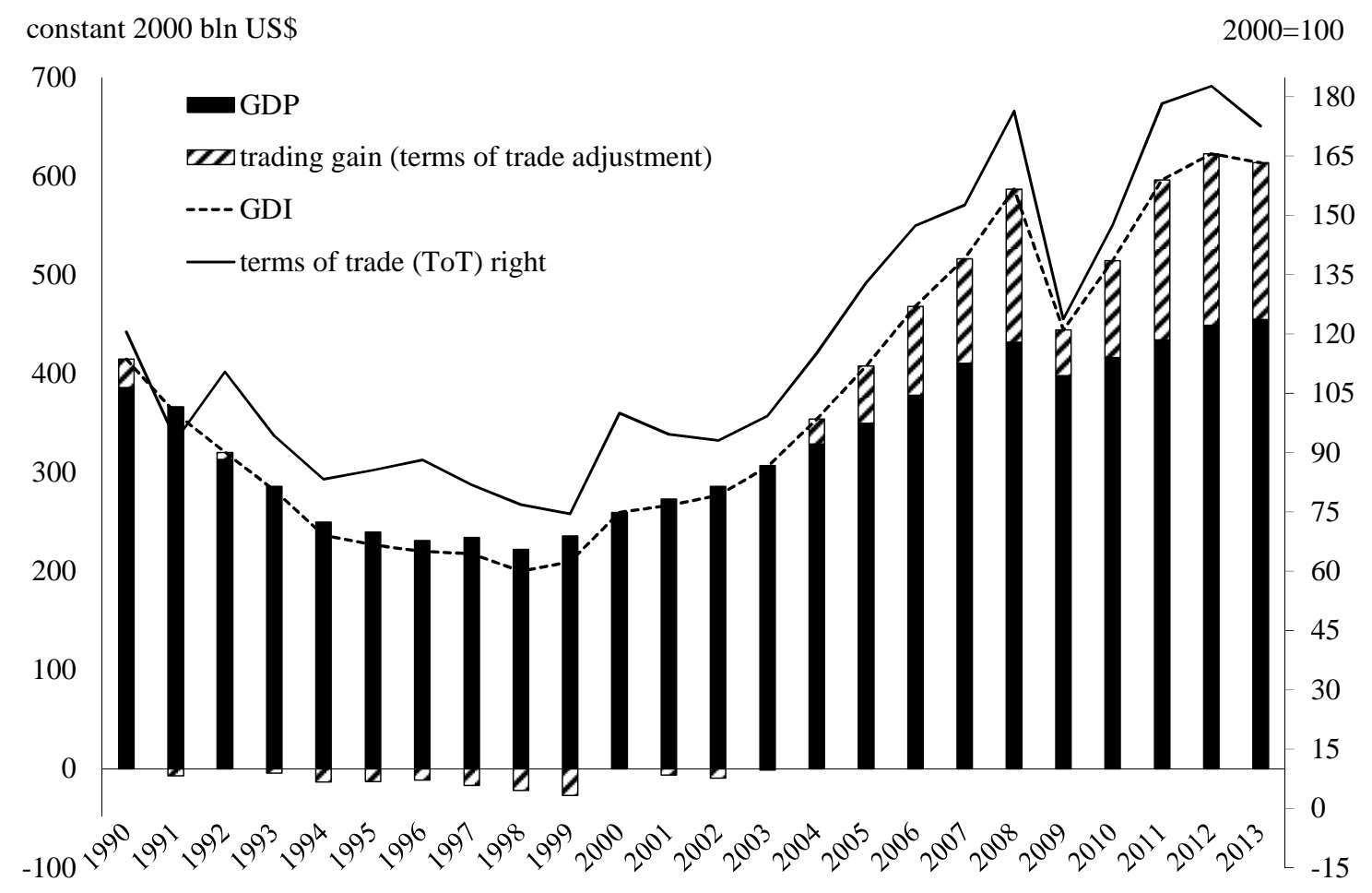

Fig. 4. Trading gains (terms of trade adjustment) at constant 2000 US\$

Source: Author's estimation based on WDI (access on August 15, 2014).

Figure 4 demonstrates that improvements in the ToT brought about trading gains or terms of trade adjustments. The trading gain in 2000 constant prices amounted to USD 155 billion in 2008 (36 per cent of GDP). In 2009 it fell down to USD 46 
billion (12 per cent of GDP). Then, it showed a continuous recovery and amounted to USD 162 billion (37 per cent of GDP) in 2012 and USD 174 billion (39 per cent of GDP) in 2013. Kuboniwa (2012) clarified a strong positive impact of oil prices on GDP through the channel of terms of trade or trading gains. In addition, Kuboniwa (2014) demonstrates the impact of increases in oil prices on GDP through another channel, namely improved energy efficiency in Russia.

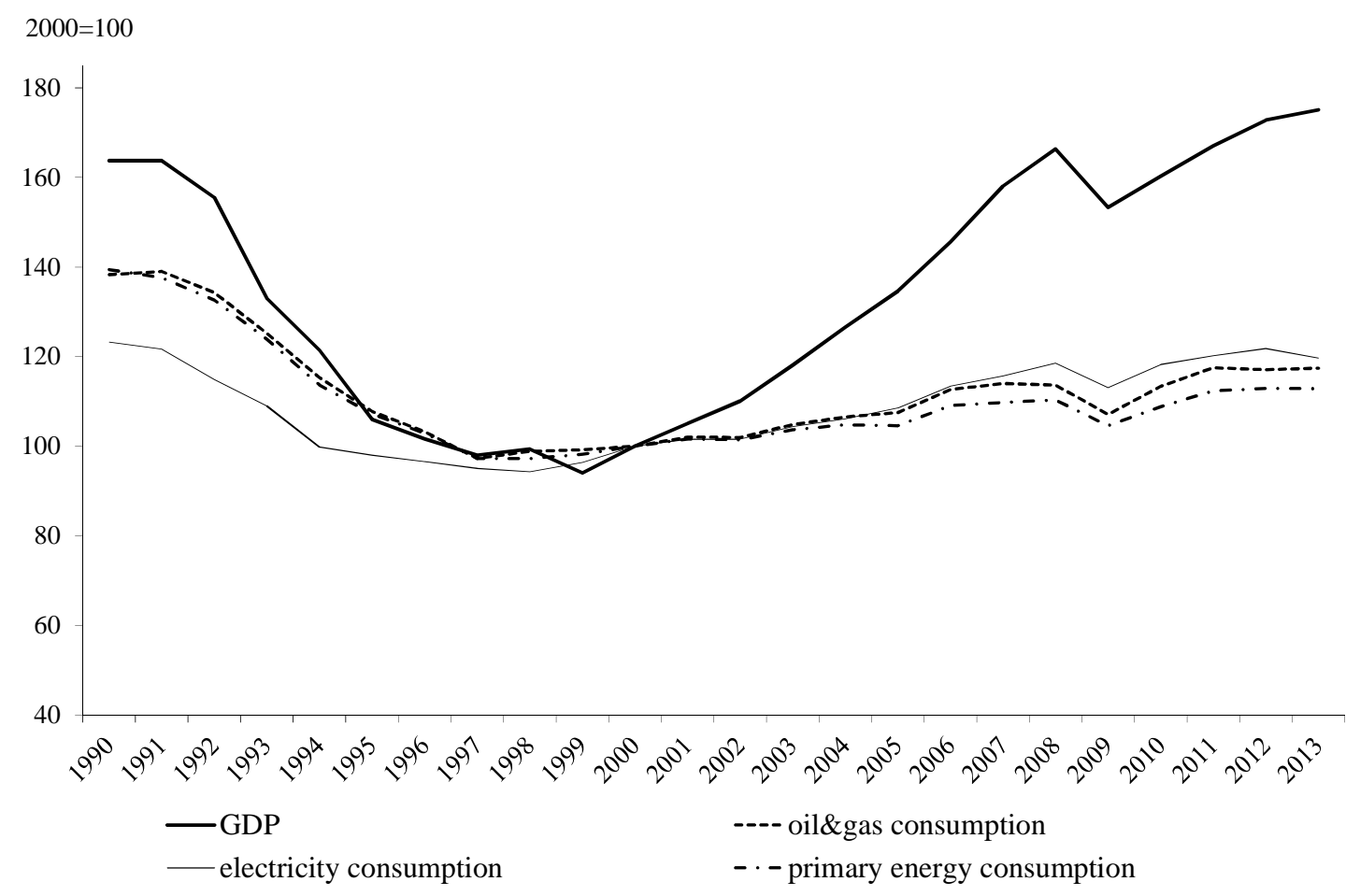

Fig. 5 Increase in energy efficiency (decreases in energy intensity)

Source: BP (2014) and Rosstat website.

Figure 5 shows movements of energy consumption including the oil and gas consumption, the electricity consumption and total primary energy consumption along 
with real GDP for 1990-2013. There were energy saving efforts in Russia in the 2000s although the absolute level of energy consumption is still very high, also as compared to other emerging economies and developed countries. Unlike the Soviet Union, the present Russia was forced to save energy in response to rising domestic prices for oil and gas due to increases in their international prices even though domestic prices for crude oil and gas are still much lower than their international prices. Improvements in the energy efficiency or the energy intensity of a country have a direct impact on its further modernization or total factor productivity (TFP).

\section{Present situation of the impact of oil prices and TFP}

Figure 6 shows the seasonally adjusted quarterly real GDP of Russia, with quarterly nominal Urals oil prices for 1995Q1-2014Q2. ${ }^{2}$ As shown by this figure, Russia faced a 5.2 per cent contraction of GDP in 1998 during the Russian financial crisis, with falling oil prices. Russia recovered quickly from its recession and showed a steady growth with rising oil prices for 2000-7. During this period, Russia grew at an annual average rate of 6.7 per cent. In 2009, due to the world financial crisis coupled with the collapse of the oil bubble, Russia showed a large decline in its GDP, minus 7.8 per cent. Russia witnessed a rather strong recovery immediately after the world financial crisis in 20089. However, it has begun to show growth retardation with a growth rate of 1.3 per cent in 2013.

${ }^{2} \mathrm{Q} 1, \mathrm{Q} 2$ etc denote the first quarter of the year, the second quarter etc. 


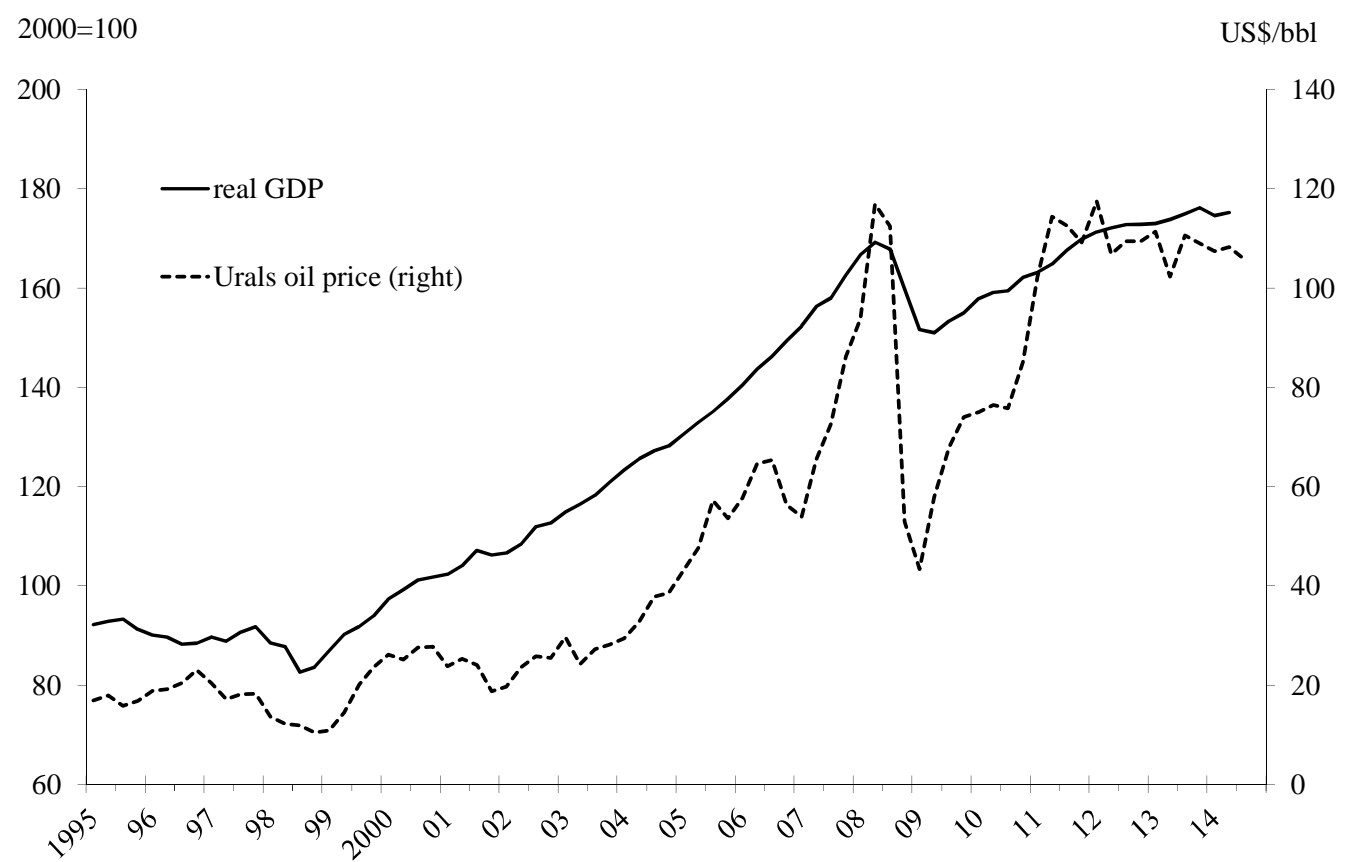

Fig. 6. GDP growth and oil prices

Source: Rosstat website and Bloomberg-Thomson Reuters.

Using DOLS (dynamic OLS) for the sample 1995Q3-2014Q2,

$g d p=0.181$ oil $+0.0056 \mathrm{t}$ (annualized trend rate of $2.3 \%$ ), Adj. $\mathrm{R}^{2}=0.972$,

[4.803] [4.453]

where $g d p=\log ($ real GDP $)$, oil $=\log ($ oil price $), \mathrm{t}=$ a linear time trend and [.] denotes t-statistic. Cointegrating equation 4 shows the long-run relationship between changes in real GDP and nominal Urals oil prices, that is to say, $\{g d p$, oil $\}$. Oil prices for Russia are Urals oil prices. The correlation coefficient between the logarithms of Brent and Urals oil prices is 0.999 .

It follows from equation 4 that a 10 per cent increase in oil prices leads to about a 1.8 per cent increase in the growth of Russia's GDP. The underlying annualized growth trend of about 2.3 per cent approximately corresponds to the TFP growth, which 
reflects Russia's modernization processes. Equation 4 thus shows the long-run relationship between growth in total factor productivity, oil prices and GDP. Both oil prices and TFP contributed to economic growth in the 2000s (Kuboniwa 2012, 2014).

When using DOLS for sample (adjusted) 2008Q2-2013Q2, the cointegrating equation is

$g d p=0.110$ oil $+0.0037 \mathrm{t}$ (annualized trend rate of $1.5 \%$ ), Adj. $\mathrm{R}^{2}=0.985$.

[8.610] [9.160]

Equation 5 implies that a 10 per cent increase in oil prices leads to only a 1 per cent increase in GDP growth. The underlying annualized growth trend of about 1.5 per cent is much less than 2.3 per cent. Both elasticity with respect to oil prices and TFP fell down markedly during these several years. Considering that the oil price decreased by 2.2 per cent in 2013, equation 5 quite well approximates the growth result in 2013 $\left(0.11^{*}-2.2\right.$ per cent +1.5 per cent $=1.3$ per cent $)$

Consider a Cobb-Douglas production function with a steady technical progress: $\mathrm{Y}=\operatorname{Aexp}(\lambda t) \mathrm{K}^{\alpha} \mathrm{L}^{1-\alpha}$, where $\mathrm{Y}=$ real GDP, $\mathrm{K}=$ capital stock adjusted for utilization based on the REB (Russian Economic Barometer), $\mathrm{L}=$ actual employment, $\lambda=\mathrm{TFP}, \alpha=$ capital distribution ratio, and $\mathrm{A}=\mathrm{a}$ constant. I estimate the linear regression: $y=\alpha k+\lambda \mathrm{t}$ $+\log \mathrm{A}$, where $y=\log (\mathrm{Y} / \mathrm{L})$ and $k=\log (\mathrm{K} / \mathrm{L})$. Data on fixed capital adjusted for utilization and employment are shown by Figure 7.7. Using a canonical co-integrating regression (CCR) for the sample 1995Q2-2013Q4 based on the data compilation method in Kuboniwa (2011),

$y=0.342 k+0.0067 \mathrm{t} \quad$ (annualized trend rate of $2.7 \%$ ). Adj. $\mathrm{R}^{2}=0.956$. 
That is to say, $\alpha=0.342$ and $\lambda=0.0067$. This implies that the capital distribution ratio accounts for 34 per cent, which corresponds to a conventional ratio, while the annualized rate of $\lambda$ (TFP) accounts for 2.7 per cent, which corresponds to a time trend coefficient of equation 4. With the sample 2009Q1-2013Q4, productivity becomes

$y=0.194 k+0.0039 t$ (annualized trend rate of $1.6 \%$ ). Adj. $R^{2}=0.979$.

$$
\text { [4.716] [4.046] }
$$

Both the capital distribution ratio and TFP show marked decreases. TFP in equation 7 corresponds to that in equation 5. This implies that the present growth retardation has been caused by large decreases in the elasticity of the capital-labour ratio and overall TFP.

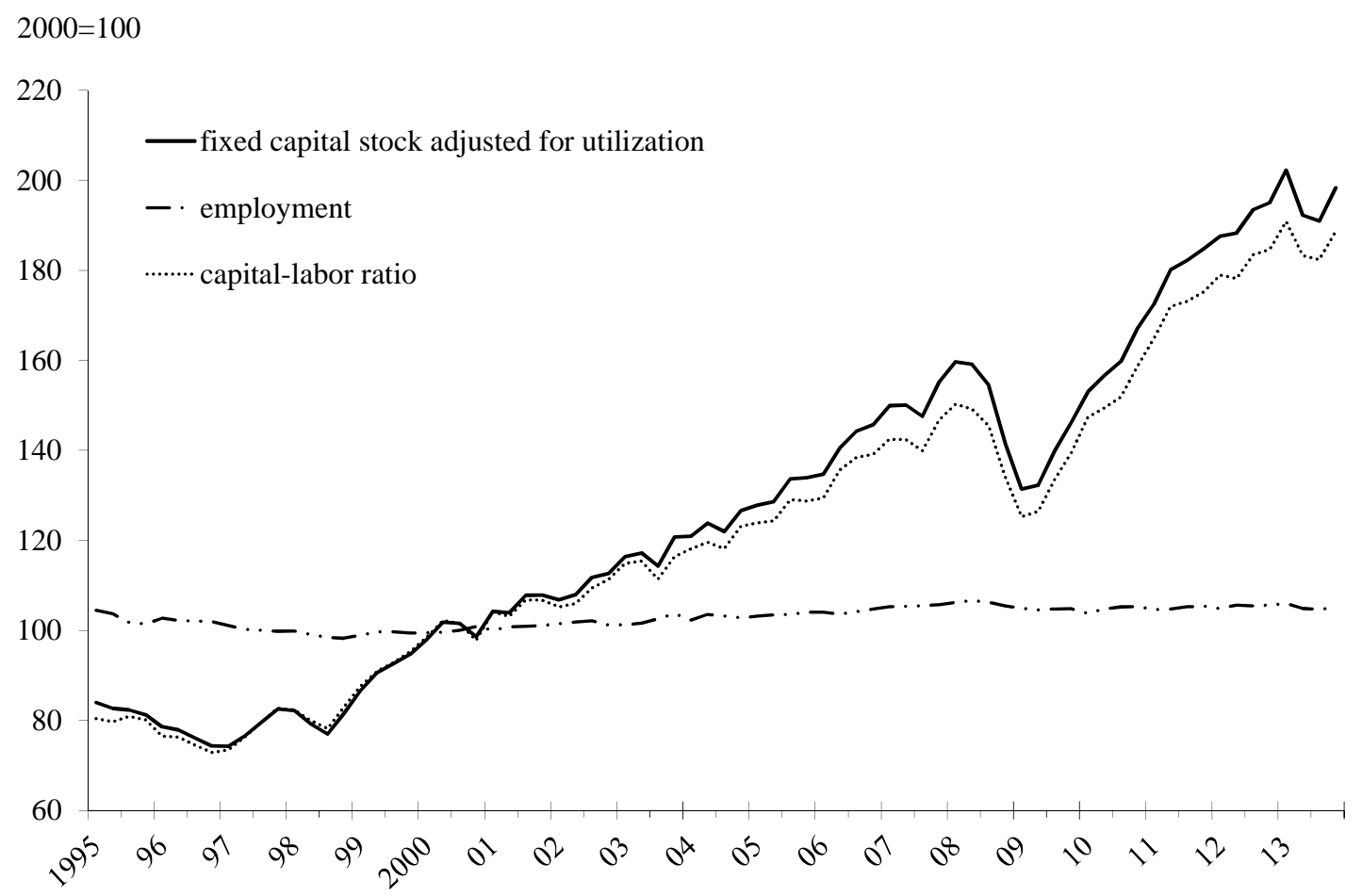

Fig. 7. Capital stock and employment

Source: Author's estimation based on data supplied by Rosstat, website of Rosstat and REB. 
It is helpful to look at manufacturing output in this context to correctly understand Russia's dependence on oil. Figure 8 presents data on the real monthly manufacturing output of Russia for 1995M01-2014M07 with its Hodrick-Prescott filter trend (lambda $=14400){ }^{3}$ Monthly data on Russia's manufacturing output for 1995-98 are estimated by using the regression based on the official data on manufacturing output for 1999-2014 and the data on industrial output for 1995-2014. International Financial Statistics (IFS) monthly data on Russian industrial output for 1995-98, which is inconsistent with quarterly and monthly data, are modified by adjusting for the official annual data for 1995-98. Russian manufacturing recovered after the world crisis and reached its pre-crisis peak level in 2013M11.

Using DOLS for sample (adjusted) for 1995M10-2014M06, we get

$$
\text { manu }=0.233 \text { oil }+0.0014 \mathrm{t}(\text { annualized trend rate of } 1.7 \%), \operatorname{adj} . \mathrm{R}^{2}=0.947
$$

where $m a n u=\log ($ real manufacturing output $)$. Equation 8 also shows a strongly positive relationship between changes in oil prices and manufacturing output for 1995-2014. It follows from this equation that a 10 per cent increase in oil prices leads to a 2.3 per cent increase in Russia's manufacturing growth. The underlying annualized trend rate of 1.7 per cent reflects TFP in manufacturing. The elasticity of manufacturing with respect to oil prices is larger than that of GDP, whereas the underlying trend of manufacturing is smaller than that of GDP. However, for the sample (adjusted) 2010M01-2014M04

\footnotetext{
${ }^{3}$ Russian official data are seasonally adjusted by X-13. X-13ARIMA-SEATS is a seasonal adjustment software developed by the United States Census Bureau.

${ }^{4}$ M stands for month. M01 is January; M11 is November, etc.
} 
In contrast to overall GDP growth, both the elasticity and trend rate for 2010-14 are slightly greater than those for the whole sample. This suggests that recent growth retardation might have been brought about through TFP losses in mining and trade sectors other than manufacturing. However, this should need further investigation. For instance, using equation 9, I approximate a manufacturing output growth of 1.3 per cent in $2013(0.241 *-2.2$ per cent +1.8 per cent $=1.3$ per cent $)$ that is much larger than the actual figure of 0.5 per cent.

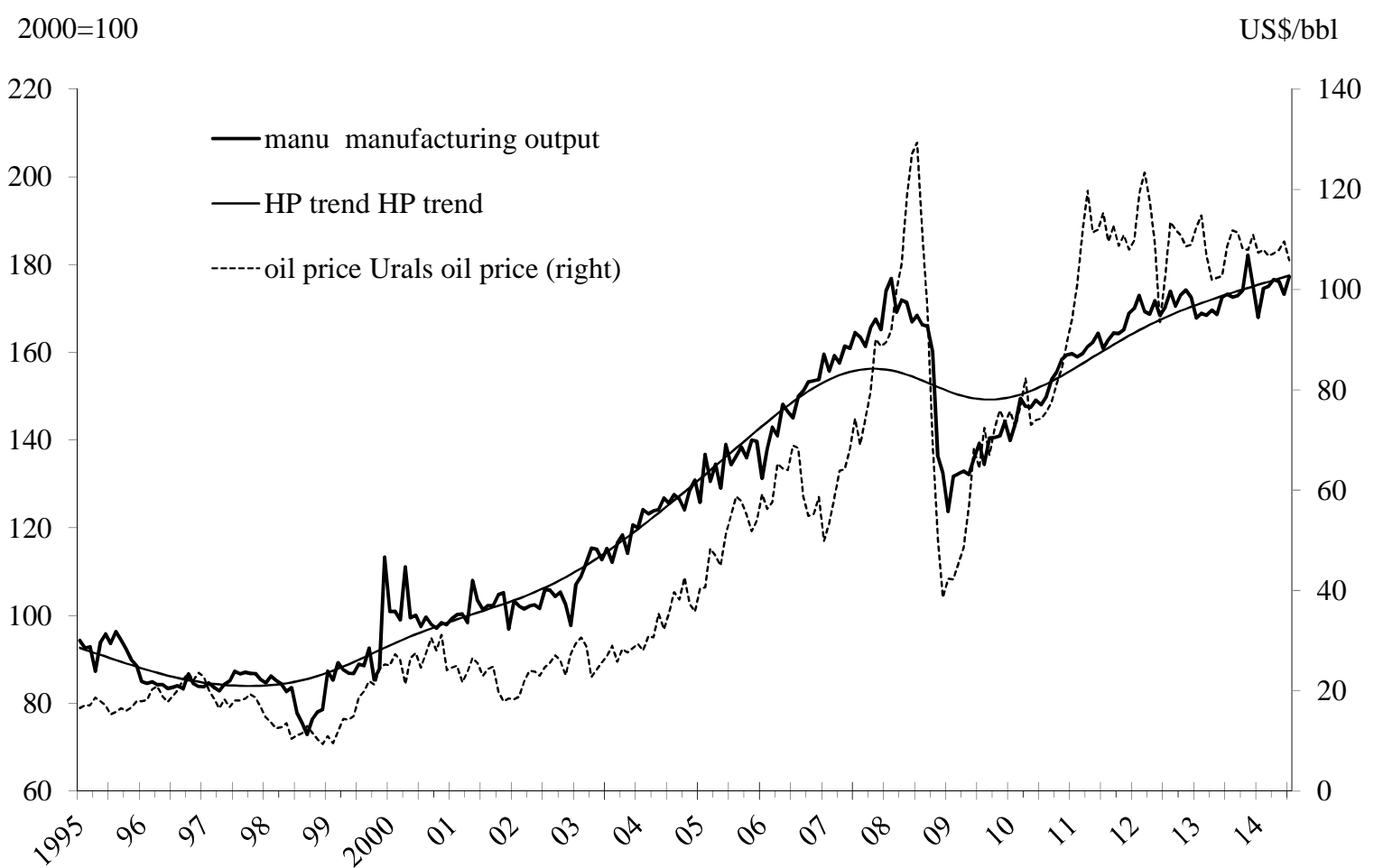

Fig. 8. Manufacturing output and oil prices

Source: Based on CEIC database and Bloomberg-Thomson Reuters. 


\section{The impact of institutional quality}

Figure 9 shows the net capital inflow/outflow of the private sector. As is well known, a large capital outflow occurred during the world financial crisis. This reflects the institutional weakness of the Russian economy. After some recovery of growth, Russia's capital inflow/outflow has shown a negative trend with rather sloppy movements. The capital outflow of about USD 60 billion in 2013 was largely brought about by Rosneft's absorption of TNK-BP. ${ }^{5}$

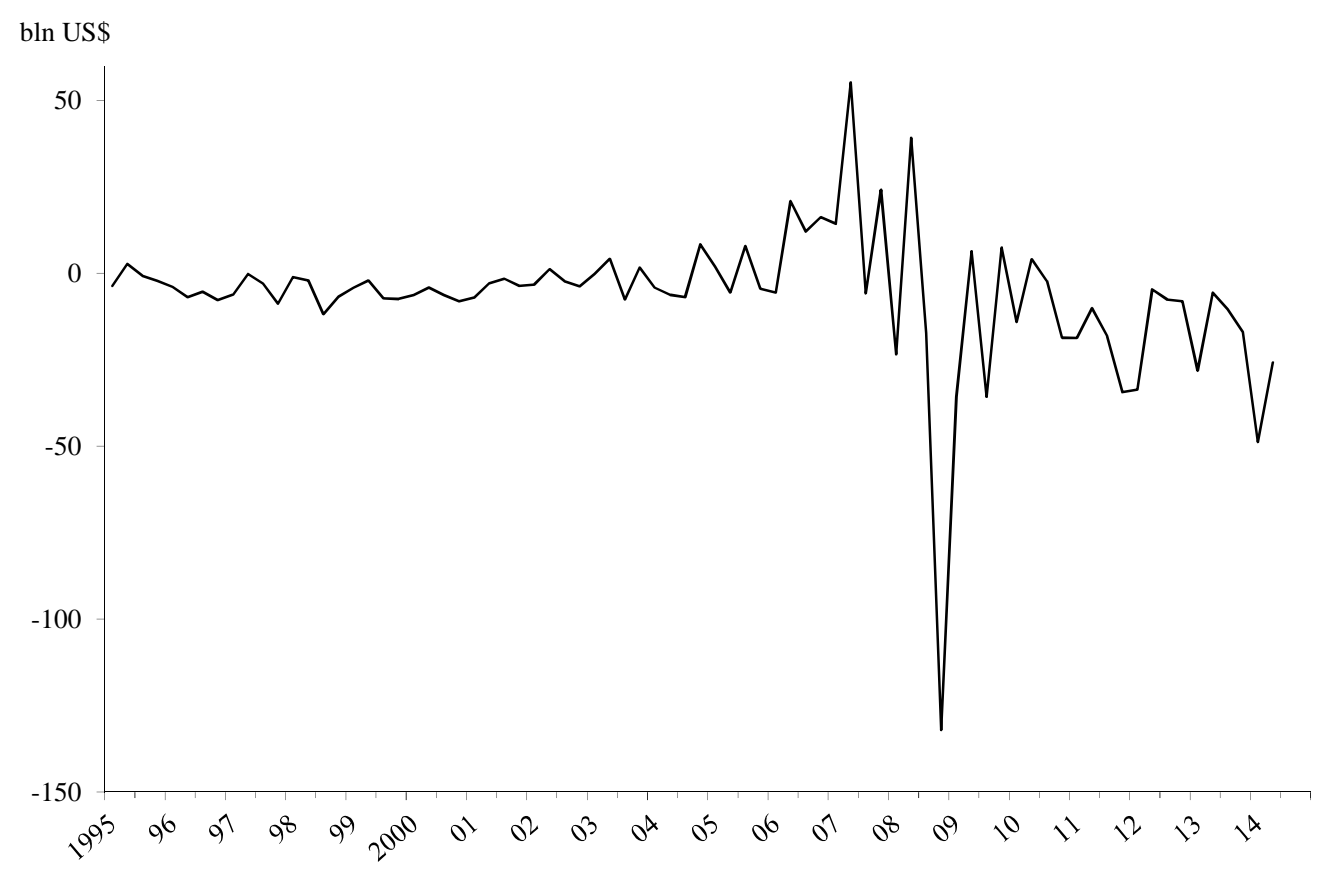

Fig. 9. Net capital inflow/outflow: private sector (bln USD)

Source: Website of Bank of Russia and CEIC database.

${ }^{5}$ This point was suggested by Professor Shinichiro Tabata. 


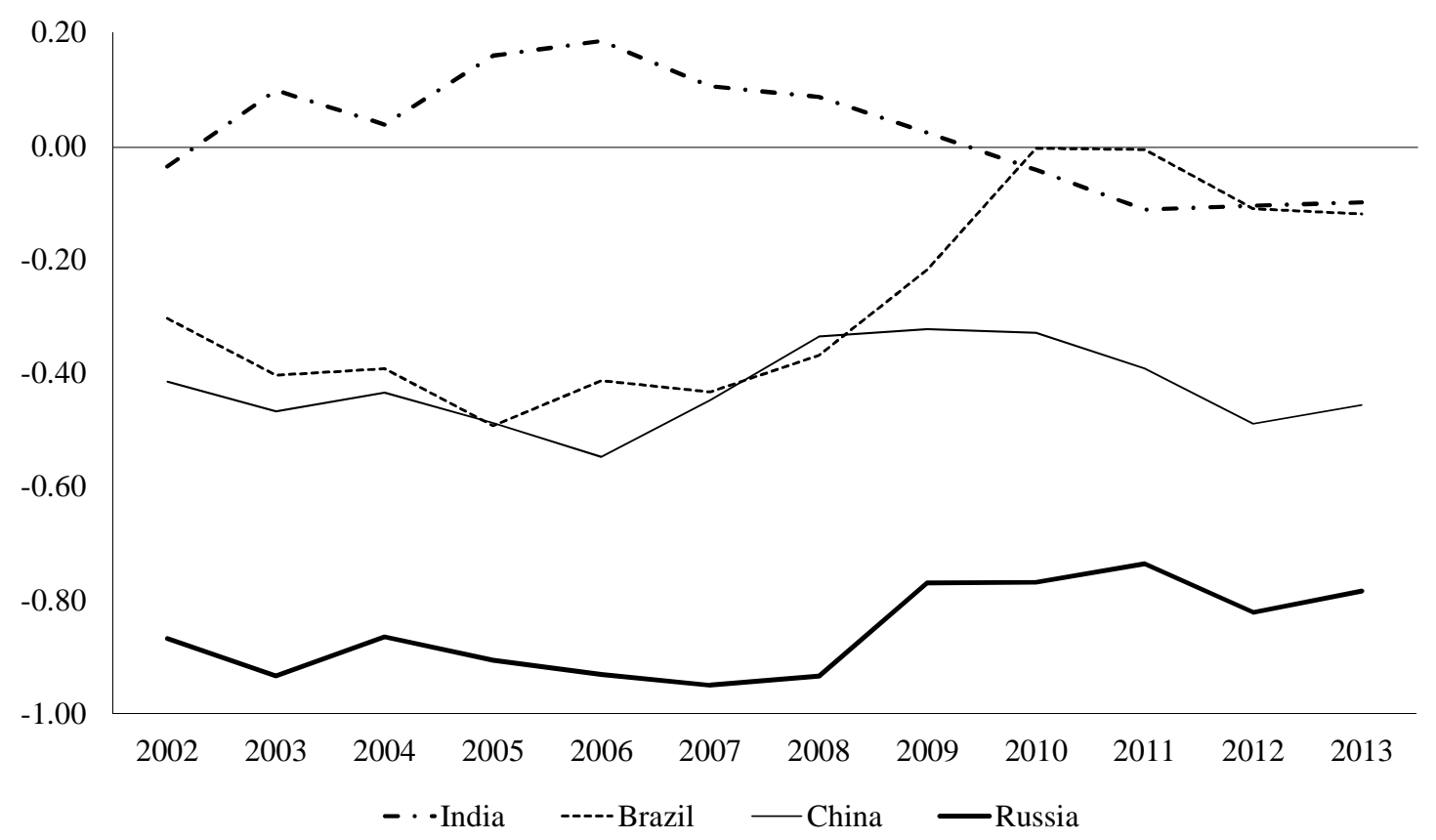

Fig. 10. Absolutely low level of worldwide governance (rule of law) of 212 countries/regions: 2014

Source: WGI (the 2014 edition).

A well-known indicator of institutional quality is the Worldwide Governance Indicators (WGI) that are the research dataset summarizing the views of the quality of governance provided by a large number of enterprises, citizen and expert survey respondents in an economy (Kaufmann et al. 2010). Figure 10 shows Russia's absolutely low level of worldwide governance (rule of law) which is ranked at the 160th of 212 countries or regions in 2013 (the 2014 edition of WGI). The top ranking is placed by an oil/gas rich country, i.e. Norway. India, Brazil and China are the 101st, the 102nd and the 128th, respectively. Russia shows an improvement during the world 
crisis in 2009. Generally, this indicator does not reflect a country's growth performance in a well-defined manner. For a small annual sample 2002-13 of Russia, I have

$$
g d p=-1.2 \log (\mathrm{WGI}+2.5)+0.05 \mathrm{t}, \mathrm{Adj} . \mathrm{R}^{2}=0.945 \text {. }
$$

Russia's GDP growth has a strongly negative relationship with the WGI that should reflect the quality of the institution.

Table 1. EoDB (Ease of doing business) as of June 2014 (of 189 countries/regions)

\begin{tabular}{lrrrrrrrr}
\hline & \multicolumn{3}{c}{ Russia } & & & \multirow{2}{*}{ China } & Brazil & India \\
\cline { 1 - 4 } \cline { 7 - 9 } & 2014 & 2013 & 2012 & & & 2014 & \\
\hline Ease of Doing Business Rank & $\mathbf{6 2}$ & 92 & 112 & & 90 & 120 & 142 \\
Starting a Business & $\mathbf{3 4}$ & 88 & 101 & & 128 & 167 & 158 \\
Dealing with Construction Permits & $\mathbf{1 5 6}$ & 178 & 178 & & 179 & 174 & 184 \\
Getting Electricity & $\mathbf{1 4 3}$ & 117 & 184 & & 124 & 19 & 137 \\
Registering Property & $\mathbf{1 2}$ & 17 & 46 & & 37 & 138 & 121 \\
Getting Credit & $\mathbf{6 1}$ & 109 & 104 & & 71 & 89 & 36 \\
Protecting Investors & $\mathbf{1 0 0}$ & 115 & 117 & & 132 & 35 & 7 \\
Paying Taxes & $\mathbf{4 9}$ & 56 & 64 & & 120 & 177 & 156 \\
Trading Across Borders & $\mathbf{1 5 5}$ & 157 & 162 & & 98 & 123 & 126 \\
Enforcing Contracts & $\mathbf{1 4}$ & 10 & 11 & & 35 & 118 & 186 \\
Resolving Insolvency & $\mathbf{6 5}$ & 55 & 53 & & 53 & 55 & 137 \\
\hline average & $\mathbf{7 9}$ & 90 & 102 & & $\mathbf{9 8}$ & $\mathbf{1 1 0}$ & $\mathbf{1 2 5}$ \\
\hline
\end{tabular}

Source: http://www.doingbusiness.org/rankings

Notes: Average scores are author's calculations.

The number of ranked countries is 189 . 
Another well-known indicator of the quality of a country's investment climate is the ease of doing business index. A high ranking on this index means that the regulatory environment is more conducive to starting and operating a local firm. This index averages the country's percentile rankings on 10 topics, made up of a variety of indicators, giving equal weight to each topic. The latest ranking is benchmarked to June 2014.

Table 1 shows this index for Russia and other BRIC countries. The 2013-2014 editions presented new opportunities for foreign companies and investors, bearing in mind that Russia moved up 30 places from 2013 to 2014 and 19 places from 2012 to 2013. Russia is the top-ranked BRIC country, coming out ahead of China (90th), Brazil (120th) and India (142nd). These change pleased President Vladimir Putin, and many expected a higher growth in 2013 and 2014. However, the growth results in 2013 and the first half of 2014 were rather disappointing. Russia's moving up in 2013 was due to a large improvement of 'getting electricity' from the 184th place to the 117th place. After the break-up of the Unified Energy System, there are many players including the generator, local governments, and private distributors' intermediate, and 'getting electricity' is not a transparent process. For instance, Nissan in St. Petersburg was forced to pay USD five million to get electricity (author's interview at Nissan in Japan). 
The ranking of "getting electricity" moved back to the 143rd in 2014 whereas that of “stating business" moved up 54 places from 2013 to 2014. Anyway, this indicator does not reflect a country's growth and investment opportunities in the short run. In general, it is complicated to design a good index of the quality of institutions in relation to the economic growth of a single country.

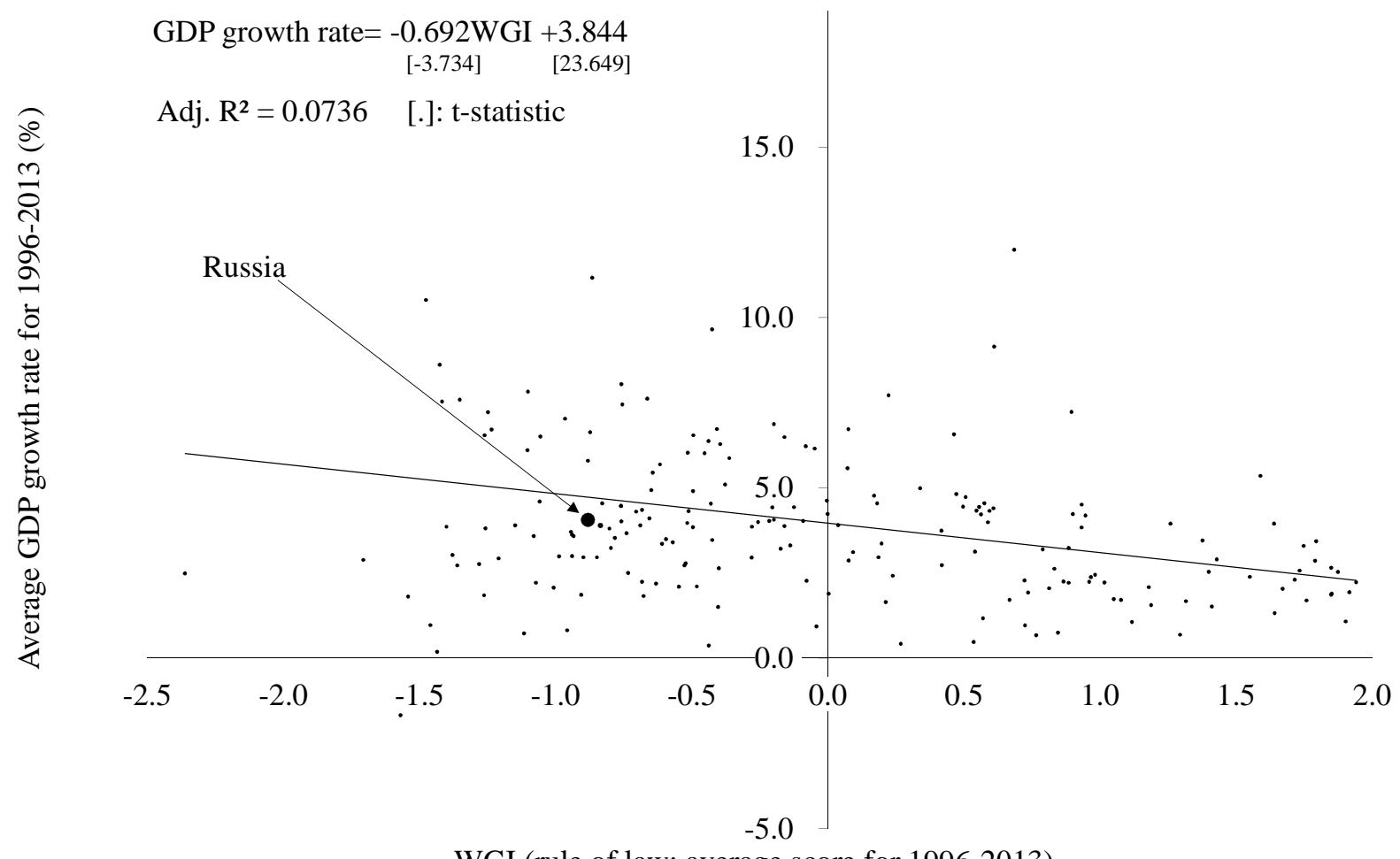

WGI (rule of law; average score for 1996-2013)

Fig. 11. Growth and institutional quality (samples of 194 countries/regions)

Source: Compiled by the author, using WGI, WDI and CEIC.

Figure 11 shows a weakly negative relationship between the arithmetic average scores of WGI (rule of law) and the geometric average GDP growth rates of 194 
countries for $1996-2013 .{ }^{6}$ Russia's position of (WGI, growth rate) of $(-0.88,4.1 \%)$ locates on a neighbourhood of the linear regression line. Roughly, a lower level of the institutional quality captured by WGI may result in a higher economic growth. On the other hand, Figure 12 demonstrates a strongly positive relationship between the average scores of WGI and the average GDP per capita of the 194 countries. Clearly, a better quality of the institution of a country captured by WGI may lead to its higher per capita income. Russia's position of (WGI, GDP per capita) of (-0.88, USD 6,464) locates on a neighbourhood of the exponential regression line. China's position of $(-0.43$, USD 2,525) cannot be an outlier in the space of (WGI, GDP per capita). There are several outliers in this space, including Monaco of (0.88, USD 121,940), Luxembourg of (1.79, USD 77,171) and Norway of (1.92, USD 63,740). Monaco and Luxembourg are international financial centers with a tax heaven. Per capita exports of the oil and gas of Norway is about 20 times those of Russia. Up to some development level, the deepening of the institutional badness such as corruption of a country may increase

\footnotetext{
${ }^{6}$ Averages of growth rates and current GDP per capita are calculated by using the GDP data in WDI. The United Nations GDP database and the national official data (the CEIC database) are employed for North Korea and Taiwan respectively. We employ the average growth rates and GDP per capita during 1996-2012 for 16 countries/regions (the Bahamas, Barbados, Bermuda, Cuba, Greenland, Jamaica, Kuwait, North Korea, Liechtenstein, Monaco, Myanmar, San Marino, Somalia, Syria, United Arab Emirates, and the West Bank and Gaza).
} 
economic growth. ${ }^{7}$ In this context, Russia still remains at a developing stage with a mutually complementary or dependent relation of institutional deficiency and growth.

However, anyhow, Russia's catch-up with the per capita income level of advanced countries decisively needs a radical evolution in its institutional quality in the long-run.

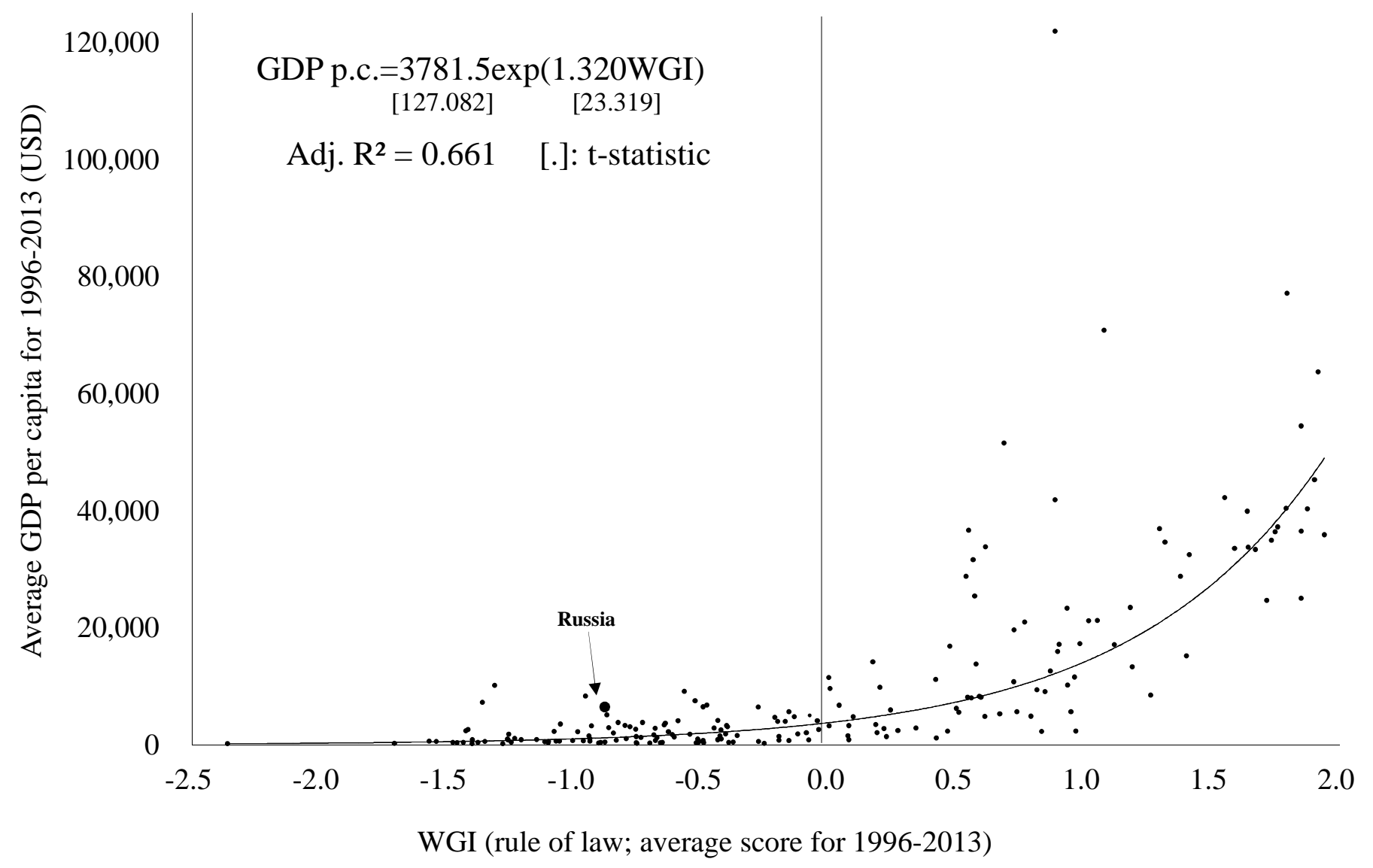

Fig. 12. GDP per capita and institutional Quality (samples of 194 countries/regions)

Source: Compiled by the author, using WGI, WDI and CEIC.

7 This point was suggested by Professor Katsuji Nakagane, based on Wedeman (2012) and Ahmad et al. (2012). Wedeman (2012: 178) found a weakly hump-shaped relationship between the Transparency International Corruption Perceptions Index (CPI) score (inverted) or national corruption and the average growth of many countries for 1992-2008. Ahmad et al. (2012) also statistically found the existence of a hump-shaped relationship between corruption and growth, using the International Country Risk Guide corruption index of 71 countries. 
In Russia, as is shown by Figure 13, even the assembly of foreign-made automobiles is facing declining growth due to its narrow technological base. To sum up, it is difficult to identify some major breakthrough leading to the subsequent development of the Russian economy beyond today's declining growth.

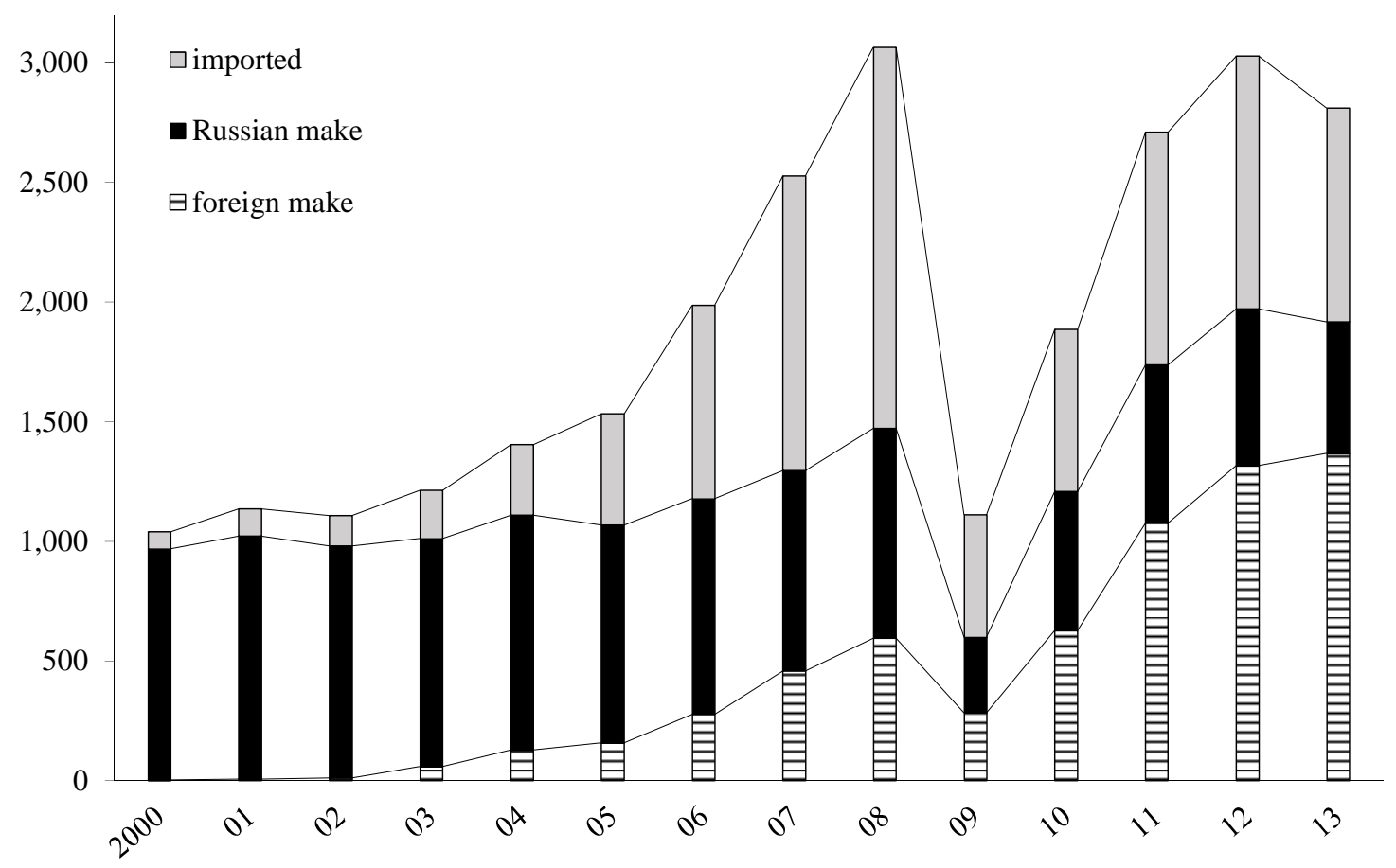

Fig. 13. Russian Car Market: 2000-2013 (thousand units)

Source: Autostat, CEIC and author's estimates.

\section{Concluding remarks}

Russia's recent economic slowdown has been analysed from the perspectives of oil prices, TFP and institutional quality. Overall declining growth can be captured by the 
impact of oil prices and TFP, whereas the estimated TFP decline does not well explain the growth of output in manufacturing. Indexes of quality of institutions including WGI and the ranking in the World Banks's ease of doing business are not sufficient to capture the output performance in present Russia. It is rather difficult to find some major breakthrough leading to a further diversification development of the Russian economy. Furthermore, in spite of president Putin's presence strongly supported by Russia's "elusive and invisible nationalism" (a key factor of its informal institutions), recent developments in Russia-Ukraine relations may deepen Russia's declining growth more than what was expected at the beginning of 2014. 


\section{References}

Ahmad, E., Ullah, M. and Arfeen, M. (2012) 'Does corruption affect economic growth?', Latin American Journal of Economics, 40: 277-305.

BP (2014) BP Statistical Review of World Energy 2014, BP: London.

Gaddy, C. and Ickes, B. (2010) 'Russia after the global financial crisis', Eurasian Geography and Economics, 51(3): 281-311.

Gaddy, C. and Ickes, B. (2013) 'Russia's dependence on resources', in Alexeev, M. and Shlomo, W. (eds.), The Russian Economy, Oxford and New York: Oxford University Press, 309-40.

Goldman, M. (2008) Petrostate: Putin, Power, and the New Russia, New York: Oxford University Press.

Kaufmann, D., Aart Kraay, A. and Mastruzzi, M. (2010) 'The worldwide governance indicators: methodology and analytical issues', World Bank Policy Research Working Paper 5430.

Kuboniwa, M. (2011) 'Russian growth path and TFP changes in light of the estimation of production function using quarterly data', Post-Communist Economies, 23(3): $311-25$. 
Kuboniwa, M. (2012) 'Diagnosing the "Russian disease": growth and structure of the Russian economy', Comparative Economic Studies, 54(1): 121-48.

Kuboniwa, M. (2014) 'A comparative analysis of the impact of oil prices on oil-rich emerging economies in the Pacific rim', Journal of Comparative Economics, 42(2): 328-39.

Kuboniwa, M., Tabata, S. and Ustinova, N. (2005) 'How large is the oil and gas sector of Russia? A research report', Eurasian Geography and Economics, 46(1): 68-76.

United Nations, Commission of the European Communities, IMF, OECD and World Bank (2008) System of National Accounts 2008 (SNA 2008). Online. Available: http://unstats.un.org/unsd/nationalaccount/sna2008.asp (accessed March 2014).

Ustinova, N. (2010) 'Oil and gas sector in Russian supply and use tables', paper presented at the 18th International Input-Output Conference, Sydney, Australia, 20-25 June 2010.

Wedeman, A. (2012) Double Paradox: Rapid Growth and Rising Corruption in China, Ithaca and London: Cornell University Press. 